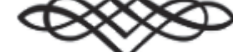

Virtudes morales e intelectuales: sobre la relación entre la contemplación desapegada y la prudencia política

\title{
Moral and Intellectual Virtues: On the Relation between Detached Contemplation and Political Prudence
}

\author{
Diego Enrique Vega Castro \\ Benemérita Universidad Autónoma de Puebla (BUAP) \\ diegovegacastro@outlook.com \\ DOI: https://doi.org/10.15366/bp2021.27.001 \\ Bajo Palabra. II Época. No 27. Pgs: 21-44
}


Recibido: 25/10/2020

Aprobado: 07/05/2021

\begin{abstract}
The classical Aristotelean distinction between moral and intellectual virtues has come to us as one of the first explicit conceptualizations of a realm of knowledge and a realm of action. This paper intends to analyze the meaning of that distinction according to an alternative hypothesis, namely, that the moral and intellectual virtues correspond to a profound understanding of the relation between the philosophical and the political life. The analysis will be guided by the relatively unclear relation between phrónesis and sophia, and by the subtle but remarkable differences that Thomas Aquinas introduces in his systematization of virtues, e.g., his explicit flight from this life as the goal of contemplation. Aquinas' understanding of theoria or contemplation will shed light on the basis of Aristotle's concern with virtues-the tension between philosophy and politics that must be mediated by a resourceful prudence.
\end{abstract}

Keywords: Contemplation, Prudence, Virtues, Aristotle, Thomas Aquinas.

\section{Resumen}

La distinción clásica aristotélica entre virtudes morales e intelectual ha llegado a nosotros como una de las primeras conceptualizaciones explícitas de un ámbito de conocimiento y un ámbito de acción. Este artículo pretende analizar el significado de esa distinción según una hipótesis alternativa, a saber, que las virtudes morales e intelectuales corresponden a una profunda comprensión de la relación entre la vida filosófica y la vida política. El análisis se guiará por la relación relativamente poco clara entre phrónesis y sophía, y por las sutiles pero importantes diferencias que Tomás de Aquino introduce en su sistematización de las virtudes, v.g., su explícita huida de esta vida como la meta de la contemplación. La comprensión de Aquino sobre la theoría o contemplación alumbrará la base de la preocupación de Aristóteles por las virtudes: la tensión entre la filosofía y la política que debe ser mediada por una ingeniosa prudencia.

Palabras clave: Contemplación, Prudencia, Virtudes, Aristóteles, Tomás de Aquino. 


\section{Introduction}

Leo Strauss concludes his commentary on Aristotle's Politics (primarily on Books I-III) by showing the "seeming self-contradiction regarding the highest theme" - the seeming fact that the highest end of man and the highest end of the city coincide. How is this possible if Aristotle himself considers the highest end of the individual to be contemplation, i.e., philosophical life? The only chance for the city and man to coincide is the chance of a contemplative city. However, according to Strauss, this is nothing but the surface of Aristotle's understanding of the relation between philosophy and politics-what is best in the individual, his capacity to transcend the city by contemplation, "comes to sight only as the limit of the political." "There are no examples of cities of the highest excellence, but there are examples of men of the highest excellence, i.e., genuine philosophers.

With this remarkable reflection in mind, we pose our hypothesis in advancethe Aristotelean distinction between moral and intellectual virtues is the result of a profound understanding of the relation between philosophy and politics, rather than a mere division of two kinds of knowledge, two realms of life, or two general faculties in the human soul. ${ }^{2}$ What Strauss calls "limit" or "transcendence," indicates a tension between politics and philosophy rather than the traditional concep-

\footnotetext{
${ }^{1}$ Leo Strauss, The City and Man (U.S.A.: The University of Chicago Press, 1964), 49. Hereafter CM. See Aristotle, Nicomachean Ethics, trans. Robert Bartlett and Susan Collins (U.S.A.: The University of Chicago Press, 2011), X.8; Politics, trans. H. Rackham (G.B.: William Heinemann LTD, 1959), VII:14-15.

2 Thus Heidegger, who in his well-known courses on Aristotle tried to defend the importance of productive virtue, its relation to techné, and the original relevance of phrónesis. This defense has at its basis what he understands to be decisive and forgotten (although it is to some extent the same traditional frame) in the difference between phrónesis and sophía, namely, that there are two realms of Being presented to man. Needless to say, he is mainly concerned with those things which are related to human activity, to the pre-comprehension of the world manifested in the things we produce and use. Theoria, according to him, would be a derived or second approach to Being when compared to techné and phrónesis; the theoretical or intellectual virtues are grounded therefore in a much more original basis presented in the things we daily use and produce in our non-theoretical

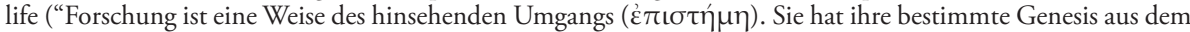
besorgend gerichteten Umgang”). Martin Heidegger, Phänomenologische Interpretationen Zu Aristoteles (Anzeige Der Hermeneutischen Situation), in Gesamtausgabe, Bd. 62, ed. G. von Neumann (Frankfurt: Vittorio Klostermann, 2005), 374. See, Diego Vega, "La $\theta \varepsilon \omega \varrho i ́ \alpha$, lo teorético (theoretisch) y lo pre-teorético (vortheoretisch) en el joven Heidegger”, Open Insight 11, núm. 23 (2020): 103-36. Unlike Heidegger, who was not interested in the political-philosophical problem already entailed in the division of virtues, we are specifically interested in the political frame wherein the division takes part.
} 
tion of a cooperation between our political or moral virtues and our speculative or theoretical capacities.

Would this mean that the Aristotelean distinction between moral and intellectual virtues hides a forgotten problem, namely, the difficulties of a philosophical life within the walls of the city? And if this is the case, why Aristotle seems to trace a rather harmonistic path from moral to intellectual virtues, e.g., by using phrónesis —an intellectual virtue — as the director of morality and action? But perhaps is even more shocking to say that contemplation (philosophy) entails a detachment from political life-something that Strauss suggests in his reflection- To this assertion one could immediately ask whether it is not a Christianized-anchoretic version of Aristotle's understanding of politics, i.e., one can reasonably ask whether Aristotle, a sober gentleman who respected the commonsense of politics, who was quite interested in virtue, friendship, and the organization of the polis, could have regarded morality and politics as an impediment to philosophize.

To this last question we address our analysis. One of the greatest difficulties to approach this problem is the justification of a non-religious view of contemplation that still considers the worldly-political realm to be in tension with philosophy. In order to understand the meaning of classical contemplation, we are compelled to examine the religious version of the distinction between moral and intellectual virtues and its respective basis; we are compelled, therefore, to understand Thomas Aquinas' systematization of virtues - and hence his ultimate position regarding contemplation. Our intention is to demonstrate that Aquinas' religious perspective of contemplation is unexpectedly more benevolent to politics than Aristotle's classical perspective. In doing so, we will show at the end how phrónesis, rather than a mere director of moral life that is in complete harmony with the intellectual life, is a political mediation between philosophy and politics.

The principal problem that leads the following examination allows us to pose the relation of some concepts with a bit of inaccuracy. For instance, we take as a general frame the pairs contemplation-action, philosophy-politics, theory-practice, intellectual-moral virtues, Metaphysics-Ethics, etc. This is not, of course, accurate; between each pair, there is a myriad of nuances. Nevertheless, we hope those flimsy relations may be able to point to an accurate direction of the problem.

\section{The place of virtues}

The traditional Distinction between $\theta \varepsilon \omega \varrho i ́ \alpha$ and $\pi \varrho \tilde{\alpha} \xi ı$ (contemplation and action) can be traced to their different objects; whereas the objects of contempla- 
tion are not subjected to change or contingency, those of action are subjected to a permanent flow and particular situations. Contemplation is usually said to be connected with divinity; action is usually said to be connected with human things. This is the frame whence Aristotle's development of two different sciences, namely Metaphysics and Ethics, finds its place - the study of eternal things and the study of changeable human things. The scientific frame permitted by this distinction was not an Aristotelean discovery, both the Platonic and the Xenophontic Socrates were completely aware of the difference between natural or divine things and human things-indeed, Socrates was perhaps the founder of that distinction. ${ }^{3}$ The problem of Socrates is of the utmost importance: although he distinguishes those natural-divine things from human things, he conceives of knowledge and virtue within a single unity.

What is the place of moral and intellectual virtues in this discussion? Although they follow the same division between eternal and changeable things, they are not only concerned with that distinction. Prudence, an intellectual virtue along with sophia (the virtue of contemplation and speculation) guides moral virtues; and moral virtues are necessary for prudence. It seems then that Aristotle finds his way to pose the dynamical interrelation between the human attitude before changeable and unchangeable things. We think, along with Strauss, that Aristotle continues and improves what Socrates made in his defense. ${ }^{4}$ What comes to us through Cicero, Xenophon, and other authors is the idea of a Socrates who was not interested in anything else but human things, in what we call good and evil within our homes. ${ }^{5}$ We believe this is the Xenophontic face of Socrates, i.e., it is part of his defense before the Athenian tribunal; the argument to be made is that Socrates was quite different from his predecessors and their radical account of theoria. As we know, those predecessors who disdained human things - who desired the knowledge of the eternal movements, the original or eternal elements-like Anaxagoras, gained political disavowal, to say the least. With the distinction between moral and

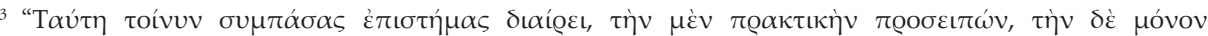

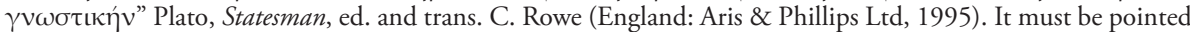
out that this division is not made by Socrates but by the Stranger of Elea. Such division seems to be rejected by Xenophon's Socratic account, but it must be carefully studied: Memorabilia, in Memorabilia-Oeconomicus-Symposium-Apology, trans. E. Marchant (London: St Edmundsbury Press Ltd, 1997), III, 9, 4-5; IV, 7, 5-7.

${ }^{4}$ It is of the utmost importance to compare Strauss' interpretation with that of Jaeger in his Aristotle, trans. Richard Robinson (Oxford: Clarendon Press, 1968), 279-83. The conflict between the individual (nay, the "philosophical ego") and the city, how to avoid the $\xi \varepsilon v ı$ cò $\beta$ ßíos, and whether there is a chance for the philosopher to find his place in politics (either through the "city in speech" or by "representing philosophic contemplation as itself a sort of creative 'action"), all these are the crucial problems which, according to Jaeger, Aristotle is posing through a profound dialogue with Plato (or, as Jaeger intends, a dialogue between the Aristotle of Politics and the Aristotle of the Protepticus).

${ }_{5}^{5}$ Cicero, Tusculan Disputations, trans. Andrew Peabody (Boston: Little, Brown, and Company, 1886).V, 4.
} 
intellectual virtues, Aristotle improves, even more (one must remember Farabi's "summary"), the relation between philosophy and politics; he even legitimates the autonomy of the study of politics within its own sphere, rather than subordinating it to philosophy or the high expectations of contemplation. For the Socratic attitude might have sounded charming, but it also meant that there could not be

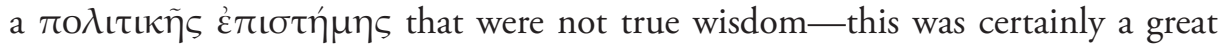
demand for politics.

We know in advance that Aristotle considers the ultimate end of human life to be contemplation, to theorize. As we posed at the beginning when we referred to Politics and Nicomachean Ethics, it is not self-evident whether or not this entails a tension with the political community, i.e., with the city. In other words, since moral virtues are always the virtues of the city, of the gentlemen, how shall we understand their relation with the highest end of human life, as a pacific nice cooperation or rather as a tension? What place has prudence in this complex interrelation? As we announced, Aquinas' examination of virtues, the highest end of human life, and his perspective of contemplation will shed light on these problems - they will indeed, by showing their deviation from Aristotle's teaching, point to, emphasize, and highlight what we consider to be the genuine concern behind Aristotle's division of virtues.

\section{A systematic distinction between moral and intellectual virtues}

Thomas Aquinas traces in his Summa Theologica (Secunda Pars, Prima Secundae) a thorough distinction between moral and intellectual virtues (q51-61). ${ }^{6}$ Putting aside some interesting reflections such as the difference between custom and habit, natural and acquired propensity, etc., we can begin by posing an introductory consideration of the "practical" difference between moral and intellectual virtues: the "intention of the end" and the "selections of the means for the end." According to Aquinas, the former is referred to moral virtue (ethics), whereas the latter is referred to prudence (i.e. one of the intellectual virtues): "those moral virtues which are concerned with the passions are in the irascible and concupiscible powers, but prudence is in the reason." $(\mathrm{q} 56, \mathrm{a} 4)^{7}$ There is thus a practical

\footnotetext{
${ }^{6}$ Thomas Aquinas, Summa Theologica, trans. Fathers of the English Dominican Province (New York: Benziger Bros, 1947).

7 On the differences that Thomas introduces to the Aristotelean account regarding the division of virtues, see Ernest Fortin, "St. Thomas Aquinas," in Leo Strauss and Joseph Cropsey, History of Political Philosophy (U.S.A.: The University of Chicago Press, 1987). Hereafter HPP.
} 
rationality that guides moral virtues and discerns the means to reach the end.

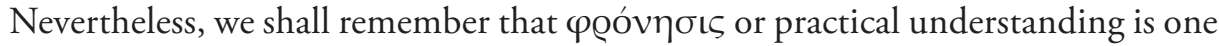

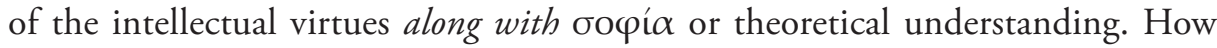
are these interrelated? Thomas follows Aristotle in that the habit of speculative science does not necessarily entail acting according to it (it seems that one can know without necessarily $d o) ;{ }^{8}$ doing depends on the will, and hence those habits that improve our will influence in the proper use of our speculative habits. In other words, the endeavor to improve our moral virtues influences our intellectual virtues, facilitates science and the knowledge of principles. If this is true, then we face the classical question: Are moral virtues meritorious by themselves or are they subordinated to a more worthwhile end-wisdom or philosophy? Thomas suggests the following: "the intellectual virtues are about those things whereby a man is made happy; both because the acts of these virtues can be meritorious, as stated above, and because they are a kind of beginning of perfect bliss, which consists in the contemplation of truth."

This appears as a subordination of morality to "the contemplation of truth."

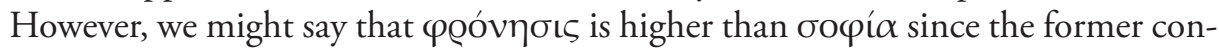
sists in the "most necessary virtue for human life" and for "living well consists in doing well." But this statement can only be granted if speculative science is (only) a part of those human actions that must be led by prudence; thus, we remain in the midst of the problem. Could it be-as a clever philosopher proposes- that

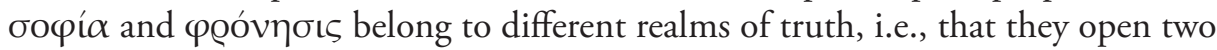

\footnotetext{
${ }^{8}$ Aristotle's assertion in NE, Book II might seem to demand not only the study of ethics but the action according to it: "Now, since the present subject is taken up, not for the sake of contemplation ( $\theta \varepsilon \omega \varrho i ́$ ( $\alpha$ ), as are others - for we are conducting an examination, not so that we may know what virtue is, but so that we may become good, since otherwise there would be no benefit from it - it is necessary to examine matters pertaining to actions, that is, how one ought to perform them." 1103b 25-30 (emphasis added). The same claim regarding the primacy of practice is usually justified by this: "by doing just things we become just; moderate things, moderate; and courageous things, courageous.", 1103b1; cf., 1179b 1-5. We must remember, however, the public to which Aristotle addresses and the intention he has with it: "Aristotle's practical science is directed not to philosophers or students of philosophy, or not principally to them, but to political men. More precisely, it is directed to educated political men who are actual or potential wielders of political power or, in the best case, to the 'legislator' who creates the constitutional framework within which all political action occurs," Carnes Lord, "Aristotle," in Strauss, HPP, 120. Cf. Strauss, CM, 25-6. It is of the utmost importance to understand this subtle suggestion-we all know that phrónesis and moral virtues are enchained to each other; however, if Strauss and the Straussians are right, this would mean a moral enchainment that is necessary within the political realm (Aristotle is educating gentlemen), but not, however, within the philosophical realm. In a few words, the fundamental question is whether sophia and theoria are enchained or subjected to moral virtues. With respect to prudence and moral virtue, Aristotle's position might be evident, but we cannot take for granted his position regarding the highest possibility of man.

9 Op. cit., q57, a1 (emphasis added). Aristotle is quite explicit when he demands the city to consider leisure as an essential condition for virtues ("peace is the end of war"). The city (e.g. the division of labor) makes possible philosophy and therefore the highest possibility of man. Whether or not this entails an ultimate tension between the ends of philosophy and the ends of politics, that is what we shall examine. See Aristotle, Pol., VII.15: 1334a.
} 
different ambits of truth? ${ }^{10}$ This seems to be suggested when Thomas re-elaborates the Aristotelian distinction:

As stated in Ethic. vi, 2, truth is not the same for the practical as for the speculative intellect. Because the truth of the speculative intellect depends on conformity between the intellect and the thing. And since the intellect cannot be infallibly in conformity with things in contingent matters, but only in necessary matters, therefore no speculative habit about contingent things is an intellectual virtue, but only such as is about necessary things. On the other hand, the truth of the practical intellect depends on conformity with right appetite. This conformity has no place in necessary matters, which are not affected by the human will; but only in contingent matters which can be effected by us, whether they be matters of interior action, or the products of external work. Hence it is only about contingent matters that an intellectual virtue is assigned to the practical intellect, viz. art, as regards things to be made, and prudence, as regards things to be done. (q57, a5)

This clarifies the respective realm of both speculative and practical intellect, and hence their respective ambit of truth. However, it is still unresolved what is the fundamental relation between them, whether there is a decisive connection, whether one is commander and the other commanded, or whether they are simply different categories, i.e., categories which are indifferent to each other. The problem is not modified at all if we proceed with the critique to the Socratic union of both: "for a man to do a good deed, it is requisite not only that his reason be well disposed by means of a habit of intellectual virtue; but also that his appetite be well disposed by means of a habit of moral virtue." (q58, a2), i.e., to possess science is not enough since passions can always resist it, and therefore they have to be controlled and trained through moral virtue-led likewise by prudence. We understand then the tension between theoretical and practical virtue; yet their interrelation, hierarchy, and the purpose of their division are not clear enough.

Perhaps those articles entitled "Whether there can be moral without intellectual virtue?" (q58, a4) and "Whether there can be intellectual without moral virtue?" (q58, a5) will shed light on our problem. To the former, Thomas answers: "Moral virtue can be without some of the intellectual virtues, viz. wisdom, science, and art; but not without understanding and prudence."; in other words, man can certainly be (morally) virtuous without a glimpse of speculative science. Regarding the latter, he says: "Other intellectual virtues can, but prudence cannot, be without moral virtue." That is to say, in order to be wise it is not necessary to be virtuous; never-

\footnotetext{
${ }^{10}$ Heidegger, op. cit., 374, 388. Needless to say, Heidegger's eccentric interpretation goes far beyond Aristotle. For a "traditional" account of theoretical wisdom (sophia) and the role of "starting-points" in experience, see Reeve, C., "Theoretical Wisdom," in Action, Contemplation, and Happiness. An Essay on Aristotle (U.S.A.: Harvard University Press, 2012).
} 
theless, prudence is utterly correlative to moral virtue: there is no virtue without prudence nor prudence without virtue. We must hold on to our question: can

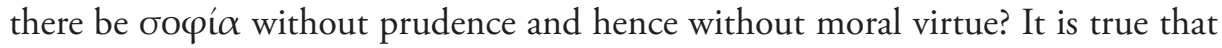
the astronomical sciences can disregard moral virtue, or that the refinement of the science of logic and dialectics can be self-sufficient without being in debt with mo-

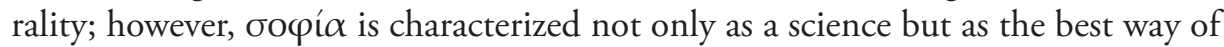
life, the ultimate realization of human essence; this turns us again to our problem: whether бофí $\alpha$ must entail prudence and prudence moral virtue.

Unlike Aristotle, Thomas is clear and explicit about the solution to this problem; for better or worse, the solution is theological. He suggests a "divine tendency" in бофí $\alpha$ that entails keeping distance from the world (which ultimately means a sort of transcendence of moral virtue). We shall remember that moral virtue is social virtue, i.e., it presupposes in each case the city, laws, customs, and other men. But, can бoфí $\alpha$ be compatible with the subjection to moral virtue, city, and its laws?

But since it behooves a man to do his utmost to strive onward even to Divine things, as even the Philosopher declares in Ethic. $\mathrm{x}, 7$, and as Scripture often admonishes us- - for instance: "Be ye ... perfect, as your heavenly Father is perfect" (Mat. 5:48), we must needs place some virtues between the social or human virtues, and the exemplar virtues which are Divine. Now these virtues differ by reason of a difference of movement and term: so that some are virtues of men who are on their way and tending towards the Divine similitude; and these are called "perfecting" virtues. Thus prudence, by contemplating the things of God, counts as nothing all things of the world, and directs all the thoughts of the soul to God alone: temperance, so far as nature allows, neglects the needs of the body; fortitude prevents the soul from being afraid of neglecting the body and rising to heavenly things; and justice consists in the soul giving a whole-hearted consent to follow the way thus proposed. (q61, a5)

Are the "perfecting" virtues those most akin to philosophy? For, certainly, the philosopher is not wise, but he desires to be wise. Granting this parallelism, the path to divine kinship entails that prudence must disregard worldly things and dedicate itself to contemplation, which means that prudence loses its inner being-its contact with the ordinary world and contingency, its closeness to human affairs as the director of moral virtue. It is necessary to emphasize this explicit flight from the human and political world. For one might say that Aquinas regards the search for truth not only as an intellectual matter but as a moral endeavor or a moral transformation. We must distinguish between the individual effort-which is, of course, also a moral effort - and the political frame wherein moral virtues and prudence take part. A prudence which "counts as nothing all things of the world, and directs all the thoughts of the soul to God alone," a justice which is not referred to politi- 
cal situations, those are not virtues referred to human things anymore within the political community. To put it again in Strauss' terms, the highest excellence of the individual is the limit of the political. Nevertheless, we must take into account the great distance between Aquinas and Aristotle that is manifested in their position toward contemplation.

\section{The ultimate end of contemplation according to Aquinas}

The theological Path proposed by Aquinas is synthetically expounded in Suma contra Gentiles. It suffices to look at the development from chap. XXV to XLVIII in Book III. Every creature is ordered toward God. The intelligent creature is intellectually ordered toward God, which means that its end, its felicity, consists in understanding or contemplating God. ${ }^{11}$ This entails-and now Thomas presents it with utmost logical determination - that the ultimate felicity is found neither in moral virtue nor in the exercising of prudence. Yet, what exactly is the contemplative activity? Since Thomas does not consider it to be the study of the first principles, we cannot take for granted its similarity with Aristotle's contemplation:

However, it is not possible for man's ultimate felicity to consist in the contemplation which depends on the understanding of principles, for that is very imperfect, being most universal, including the potential cognition of things. Also, it is the beginning, not the end, of human enquiry, coming to us from nature and not because of our search for truth. Nor, indeed, does it lie in the area of the sciences which deal with lower things, because felicity should lie in the working of the intellect in relation to the noblest objects of understanding. So, the conclusion remains that man's ultimate felicity consists in the contemplation of wisdom, based on the considering of divine matters. (chap. XXXVII)

The knowledge of God to which we refer is not then the knowledge of the first principles nor the knowledge acquired by demonstration; these are always imperfect. Their imperfection can be explained at least by four arguments: 1) There are very few men who reach the knowledge of God by means of demonstration; happiness is the end of the human species; therefore, human happiness, as knowledge

\footnotetext{
${ }^{11}$ And this higher dignity in contemplative activity before practice is justified by the same Aristotelean arguments: "all practical sciences, arts, and powers are objects of love only because they are means to something else, for their purpose is not knowledge but operation. But the speculative sciences are lovable for their own sake, since their end is knowledge itself. Nor do we find any action in human affairs, except speculative thought, that is not directed to some other end.", Aquinas, Summa contra Gentiles, trans. Vernon Bourke (New York: Image Books, 1956), III, chap. XXV.
} 
of God, cannot lie in demonstration, for very few men can access to it (social argument). 2) Felicity must be the complete absence of misery and pain. But the investigation of demonstrations causes misery and pain since many times we err and believe to know something which afterward turns out to be false; the conclusion repeats (hedonistic argument). 3) Knowledge requires the certainty that there will never be the case wherein our knowledge results false, i.e., it requires an utter certainty; but "the knowledge we have been talking about includes much uncertainty"; therefore, the conclusion exposed is repeated (skeptic argument). 4) The one that seems most important for our aims (philosopher's desire argument):

Moreover, the will rests its desire when it has attained the ultimate end. But the ultimate end of all human knowledge is felicity. So, that knowledge of God which, when acquired, leaves no knowledge of a knowable object to be desired is essentially this felicity. But this is not the kind of knowledge about God that the philosophers were able to get through demonstrations, because, even when we acquire this knowledge, we still desire to know other things that are not known through this knowledge. Therefore, felicity is not found in such knowledge of God. (chap. XXXIX)

These arguments highlight the fact that the philosophical knowledge is essentially imperfect, unfinished, that it does not achieve to subdue the desire of knowing more, and hence that it cannot consist in the ultimate and genuine felicity. Does this mean that Thomas subdues himself to the irrationalism of faith? By no means, since, under a very powerful argument, faith appears always subordinated to someone who actually knows the truth: a human being, a prophet, Christ. Faith is the knowledge that substitutes seeing for hearing, and in doing so we put our trust in hearsays. But if the ultimate felicity means to get first-hand knowledge of God, it is impossible to attain it through faith (chap. XL). There is a third way proposed by philosophers: the knowledge of separate substances which leads by deductions to the direct knowledge of God. Thomas rejects this by refuting Avempace, Alexander, and Averroes. Yet what remains after having rejected every possibility of absolute knowledge and therefore of felicity? Thomas anticipates Existentialism: "a thing is futile which exists for an end which it cannot attain. So, since the end of man is felicity, to which his natural desire tends, it is not possible for the felicity of man to be placed in something that man cannot achieve. Otherwise, it would follow that man is a futile being, and his natural desire would be incapable of fulfillment, which is impossible." (XLIV) ${ }^{12}$ Thus, since it is impossible that man has

12 Cf. Harry Jaffa, Thomism and Aristotelianism (U.S.A.: The University of Chicago Press, 1952), 155-159; Klaus Oehler, "Thomas von Aquin Als Interpret Der Aristotelischen Ethik," Philosophische Rundschau 5 (1957): $135-52$. 
an unrealizable end, it is necessary to grant, according to Thomas Aquinas, that our felicity and the contemplative knowledge of God are not found in this life but in the afterlife:

On this point there is abundant evidence of how even the brilliant minds of these men suffered from the narrowness of their viewpoint. From which narrow attitudes we shall be freed if we grant in accord with the foregoing proofs that man can reach true felicity after this life, when man's soul is existing immortally. [...] And so, man's ultimate felicity will lie in the knowledge of God that the human mind has after this life, according to the way in which separate substances know Him. For which reason our Lord promises us 'a reward in heaven' (Matt. 5:12; 22:30; 18:10). (XLVIII)

Those brilliant minds are the greatest philosophers who despite their knowledge experienced anguish and pain due to their lack of knowledge of God, a knowledge that is forbidden to man in his earthly life. However, it must be emphasized that the knowledge attained in the afterlife still belongs to the contemplative kind. Thomas has begun from theoretical life and speculative knowledge, and has arrived at the confirmation of his doctrines about the immortality of the soul.

We need to restate the principal problems that have appeared so far. At the beginning, we pointed out how the Aristotelean distinction between moral and intellectual virtues continued the Socratic differentiation of natural things and human things. At the same time, we said, Aristotle posed the autonomy of what pertains to morality and what pertains to intellectuality, and hence he introduced an ambiguity, to say the least, to the alleged straightforward Socratic identification between virtue and knowledge. Through Thomas Aquinas' analysis of virtues, we have come to see the different directions of sophia and phrónesis, i.e., a tension similar to the Platonic horses of the Phaedrus — contemplation in its most perfect sense prevents prudence from the contact with worldly things, i.e., it prevents it from realizing its inner essence. The same, perhaps, can be said regarding prudence and moral virtues - they are transcended in the quest for truth.

If this reasoning is correct, we face now not only an ethical problem regarding individual happiness but a political-philosophical problem, which can be stated in the following terms: the individual can dedicate to a contemplative life, whereas the city cannot.

Nevertheless, unlike an Epicurean or conventionalist position, Thomas follows Aristotle by saying that man is a political being and his end can only be reached within the political community. His twofold argument is based on the consideration of man's corporeal weakness: "one man alone is not able to procure them all for himself, for one man could not sufficiently provide for life, 
unassisted," and in the weakness of his practical reasoning: "it is not possible for one man to arrive at a knowledge of all these things by his own individual reason. It is therefore necessary for man to live within a multitude so that each one may assist his fellows, and different men may be occupied in seeking, by their reason, to make different discoveries-one, for example, in medicine, another in farming, etc." ${ }^{13}$ Shouldn't we admit that the retirement from the world toward contemplation is an explicit transgression of the natural character of the political community?

To neglect human affairs when necessity forbids is wicked; otherwise it is virtuous. Hence Cicero says a little earlier: "Perhaps one should make allowances for those who by reason of their exceptional talents have devoted themselves to learning; as also to those who have retired from public life on account of failing health, or for some other yet weightier motive; when such men yielded to others the power and renown of authority." This agrees with what Augustine says (De Civ. Dei xix, 19): "The love of truth demands a hollowed leisure; charity necessitates good works. If no one lays this burden on us we may devote ourselves to the study and contemplation of truth; but if the burden is laid on us it is to be taken up under the pressure of charity." ${ }^{14}$

Theoretical life needs to detach itself from the republic, from political activities, and if necessity do not forbid, this is virtuous. If charity (the Christian version of being morally virtuous with countrymen) is imposed by necessity, it must be accepted by necessity. This means that the range of our freedom to philosophize is limited and always framed by the res publica. How can we discern the dangerous and changeable situations that permit or forbid philosophizing in the political frame? This seems to be a task of prudence. Can we say, therefore, that $\varphi$ @óvๆoıs is an intellectual virtue that safeguards theoretical activity from political demands, rather than the access to a different realm of truth and rather than a link between morality and wisdom?

If this is the case, should we say that Thomas' subtle suggestion differs from Aristotle? As we will see, it seems that Aristotle approached in the same way to this problem. Nevertheless, the different accounts they gave about contemplation will lead us to divergent, even contrary conclusions, as we will show at the end of this paper.

\footnotetext{
13 Thomas Aquinas, On Kingship, trans. Gerald Pherald (U.S.A.: Hyperion Press, 1979), I, 5-6. Aquinas' intention is to justify Kingship or the necessity of men to be governed. If men were not social or political by nature, then everyone could be a tyrant; see, I, 11. Cf. Aquinas, Commentary on Nicomachean Ethics, trans. C. Litzinger, O.P. (Chicago: Henry Regnery Company, 1964), n. 4; Aquinas, Commentary on Aristotle's Politics, trans. Richard Regan (Indianapolis: Hackett Publishing Company, 2007), I, 1, n.18-21; Aristotle, Pol., I.2: 1253a.

14 Summa Theologica, Secunda Pars, Prima Secundae, q61, a5.
} 


\section{Some remarks on Aristotle's practical wisdom and phrónesis}

In Aristotle, we find this same dignification of contemplative life, though not radicalized as Thomas' theological point - the happiness of contemplative activity is not submitted to an other-worldly happiness. However, strange as it may seem, Aristotle is much more explicit regarding the superiority of contemplation before the polis; he is, as it were, much more explicit about the tension between philosophy and politics (even if he leaves it as an ambiguity at the end of $N E$ and Pol. VII). Whereas Thomas reflects on the tendency toward the divine and highest dignity of this activity with respect to prudence and moral virtues, Aristotle affirms it with natural strength: "For it is strange if someone supposes the political art or prudence to be most serious, if a human being is not the best of things in the cosmos." ${ }^{15}$ This assertion has a very wide meaning: prudence is the virtue of the political par excellence, of the means for reaching morally worthwhile ends; it leads the individual to become morally virtuous through the right means. Although it is fundamentally an intellectual virtue, it is rooted within the walls of the polis. Nevertheless, if human being is not the best thing in the cosmos, then the walls of the city are surpassed by contemplation. ${ }^{16}$

However, such dignity of what is not human is not disengaged from human things (here usually the argument is mishandled by assimilating it with modern natural science). ${ }^{17}$ The activity according to the highest human virtue is perfect

15 Aristotle, NE, VI.7: 1141a 15-25. This also means that the alleged "tendency" that Thomas claimed regarding moral virtue as a path to arrive at contemplation is not presented by Aristotle. We can only expect that from those addressed in $N E$ (i.e. gentlemen), there will be only a few who transcend the walls of the city: "the structure of the Nicomachean Ethics as a whole may be said to have the character of an ascent from the perspective of ordinary political or practical men to a perspective informed by philosophy, which is presented in Book X as a pursuit decisively superior to the pursuits of the practical life," Lord, op. cit., 123.

${ }^{16}$ I think this is not undermined by the fact that theory is perfect praxis. The difference between philosophical contemplation and political action (we shall remember that prudence and practice are here always related to the political community) is not merely a difference of degree. Since "man is more than the citizen or the city," (Strauss, CM, 49), theory as perfect practice cannot be understood as a harmonical culmination of moral virtues and prudence.

${ }^{17}$ Cf. Michel Foucault, The Hermeneutics of the Subject, trans. Graham Burchell (USA: Palgrave Macmillan, 2005), 17, who understands Aristotle's detached contemplation as the antecedent of sober modern natural science. Such misunderstanding comes from the fact that Aristotle admits, as Strauss points out, the possibility of simple wisdom (to perfectly know the causes of the cosmos, see Strauss, CM, 16), but this does not mean, however, that the knowledge of causes and principles is indifferent to human beings (one should remember the

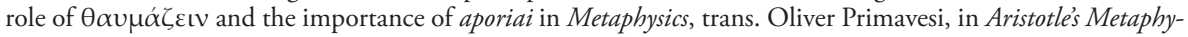
sics Alpha, ed. Carlos Steel (U.K.: Oxford University Press, 2012), I.2: 982b 11-19; for the complete English version see Metaphysics, trans. Joe Sachs (U.S.A.: Green Lion Press, 1999); cf. likewise, the role of endoxa in Aristotle, Topica, in Posterior Analytics-Topica, trans. E.S. Forster (G.B.: William Heinemann LTD, 1960), I.1: 100b 21-23, I.2: 101a 35; NE VII.1: 1145b 6-7; see a thoughtful theoretical explanation of the role of aporiai and endoxa in Aristotle's dialectical philosophy in Reeve, C., "Aristotle's Philosophical Method," in The Oxford Handbook of Aristotle, ed. Christopher Shields (Oxford: Oxford University Press, 2012)). In brief, for modern 
happiness, and if the activity corresponds to what by nature is most worthwhile in man-intellect or reason-then the contemplative activity is what is desirable by itself. Unlike prudence, always engaged with contingent ends, contemplative activity is autarchic:

The self-sufficiency spoken of would pertain especially to the contemplative life. For a wise person, a just person, and all the others are in need of the necessities of life. But when these necessities have been supplied sufficiently, the just person needs others toward whom and with whom he will act justly, and similarly with the moderate person, the courageous, and each of the rest. The wise person, by contrast, is capable of contemplating even when by himself, and the wiser he is, the more capable of doing so he will be. And though it is perhaps better to have those with whom he may work, nonetheless he is most self-sufficient. ${ }^{18}$

Besides the beautiful philosophical magnanimity of this passage, I think this is perhaps one of the major expressions of the conflict philosophy-city posed by Aristotle. Theorization is self-sufficient, it does not need anything from "countrymen." This surely entails the discontentment of citizens toward philosophers since the alleged self-sufficient activity is placed in the polis, i.e., it is not corporally autonomous. Are we not facing the citizen's genuine and archaic suspicion toward the philosopher? Furthermore, we arrive at Thomas' breaking point, for Aristotle says: "But a life of this sort would exceed what is human. For it is not insofar as he is a human being that a person will live in this way, but insofar as there is something divine present in him." ${ }^{19}$ It is unbecoming of man as man to live thus. As we are about to see, Aristotle's answer to the seeming contradiction of living according to what is divine in human being and the impossibility of living as man according

science it is a delightful accident that man can understand the laws of nature; for Aristotle, this is the end of man.

${ }^{18}$ Aristotle, NE, X.7: 1177a 25-35. What Aquinas gained in clarity regarding the systematization of virtues, he lost it regarding the tension between philosophy and politics. Aquinas does not introduce the autarchy of the philosopher when talking about kingship. This is mainly due to two reasons: Aquinas places the most perfect contemplation in the afterlife; and, second, autarchy is somehow opposed to humility. I strongly recommend seeing the contrast between the religious humility and the philosophical magnanimity as is stated by Strauss in "Reason and Revelation," in Heinrich Meier, Leo Strauss and the Theologico-Political Problem, trans. Marcus Brainard (U.S.A.: Cambridge University Press, 2006), 163. On the role of autarchy and its relation with friendship (a major theme in Aristotle), see Leo Strauss, On Tyranny, ed. Victor Gourevitch and Michael Roth (E.U.A.: The University of Chicago Press, 2000). It is worth saying that friendship is not the exception but the consequence of philosophical autarchy; genuine philosophical friendship is only possible through the freedom that autarchy supplies.

19 NE, X.7: 1177b 25. On the problem of man qua moral being and man qua divine being, see Jaffa, op. cit., 149151. This commentary goes in a different direction from ours; nevertheless, it is not improbable that it would agree with the present approach. 
to what is divine in human being, is found in the role of prudence and political wisdom. ${ }^{20}$

The above is not refuted by that fragment of Politics wherein Aristotle says that "to praise inaction more highly than action is an error, for happiness is an activity, and further the actions of the just and temperate have in them the realization of much that is noble." ${ }^{21}$ For Aristotle considers happiness to be an activity at the same time that he understands contemplation as the highest end of man, and hence the highest happiness possible. Of course it is an error to praise inaction in a book addressed to human action! Aristotle thus leaves us the problem to solve whether contemplation can ultimately be conciliated with a life of political action.

Finally, we are compelled to question the role of phrónesis as an intellectual virtue in philosophy. If the ultimate end of philosophy is theoria or contemplation, and if prudence is always related to changeable human things, what is then the purpose of phrónesis? The following subtle clue might shed light on this:

it is clear that wisdom is a science and intellectual grasp [nous] of the things most honorable by nature. Hence people deny that Anaxagoras, Thales, and the wise of that sort are prudent when they see them being ignorant [ $\dot{\alpha} \gamma$ vooṽv $v \alpha \varsigma$ ] of the things advantageous

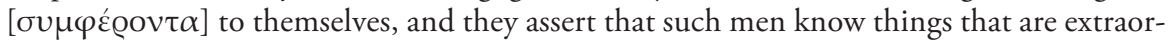
dinary, wondrous, difficult, and daimonic — yet useless too because they do not investigate the human goods. ${ }^{22}$

This is usually understood in the same manner as the division between moral and intellectual virtues, i.e., merely as a distinction of two kinds of knowledge. However, this view is just partially right; Aristotle's differentiation of scientific and practical knowledge is a political differentiation. ${ }^{23}$ His criticism of the Pre-Socratics addresses to their lack of prudence or practical knowledge. We might say that prudence is a

${ }^{20}$ As Reeve sharply points out (Action, Contemplation..., 234-8), the self-sufficiency has two senses — there is some particular sort of human life, the theoretical, that is completely autarchic; and there cannot be any sort of human life that is completely autarchic since this is reserved to contemplative gods whose activity is contemplation alone; see Aristotle, Met. XII.7: 1072b. One must remember, however, that in the referred quotation (NE, X.7: 1177a 25-35) Aristotle speaks of human relations, and therefore we are permitted to think in the highest form of human autarchic life without contrasting it with divine autarchy.

${ }^{21}$ Aristotle, Pol., VII.3: 1325a 3. We face again the problem of Aristotle's rhetorical or even exoteric direction: "the possibility must at least be considered that Aristotle's political writings are in their own way as radically ironic as those of Plato- that they deliberately withhold Aristotle's final or most fundamental reflections on man.” Lord, op. cit., 121. Cf. Leo Strauss, Natural Right and History (U.S.A.: The University of Chicago Press, 1965), 136-137.

22 NE, VI.7: 1141a30-b5. From other point of view, Aristotle is utterly following Socrates. Cf. Xenophon, op. cit., IV, 7, 5-7. For the Greek edition, see Ethica Nicomachea, ed. J. Bywater (Oxford: Clarendon Press, 1894).

23 See Svetozar Minkov, Leo Strauss on Science (U.S.A.: State University of New York Press, 2016), 202, n7; Heinrich Meier, "Why Political Philosophy?," The Review of Metaphysics 56, no. 2 (2002), 403-4. 
fundamental part of wisdom properly understood, yet the emphasis has to be put on its political importance: the Pre-Socratics are ignorant of what is advantageous not in general but especially to themselves, i.e., they are politically incapable of defending and justifying their own activity; they lack self-knowledge and hence political prudence. The philosopher who does not know whether his neighbor is a man or other kind of creature, as in the description in the Theaetetus, is not just misguided regarding wisdom but—as we have tried to accentuate- politically untenable. Natural philosophers were indeed called wise, though they lacked prudence; they had knowledge about the most worthwhile things, those closest to divinity, but they lacked knowledge of human affairs, they lacked political wisdom. Prudence then seems to be the political protective link between philosophy and politics. This is what classical political philosophy gained over the Pre-Socratics, and surely what made possible the development of philosophy inside the always unstable walls of the city. Prudence has therefore, a role of the utmost importance; however, as we have shown by this alternative interpretation, its importance does not lie in a harmonical and noble union between morality and philosophy, but rather in a bridge that protects the theoretical interests of philosophy at the same time it precludes the insanity of a radical natural philosophy that is not interested at all in human things (and which is, then, completely vulnerable to political tensions). Whether this was also Aquinas' understanding of the division of virtues, the role of phrónesis, and the philosophical impossibility of an explicitly detached contemplation, I will suggest some final answers in the conclusion.

\section{Concluding remarks}

There are two COnCluding Remarks which need to be pointed out. The first one is the important difference within the similarity between Aristotle and Thomas regarding contemplation (and hence regarding their understanding of the tension between intellectual and moral virtues).

Although Aquinas was aware of the "burden" that political or worldly things meant to the "contemplation of truth," we must notice that what he understood by contemplation may lead us to a completely different comprehension of what Aristotle understood by the relation of politics and philosophy. This is expressed in Thomas' idea of his own endeavor: he treats the end of man and his happiness related to the ultimate genuine end, i.e., the afterlife, whereas Aristotle treats it within this worldly life. ${ }^{24}$ Furthermore, if we consider that the Thomist contem-

${ }^{24}$ See Aquinas, Commentary on Nicomachean Ethics, n. 588, 590. Cf. Jaffa, op. cit., 159. 
plation is not possible in the strict sense in this life but only after death, there is no justification for a real conflict between philosophy and politics, at least not as profound as it seems to be in the classical account. ${ }^{25}$ The great expression of this difference can be found in the thorough study by Leo Strauss on natural right. In a few words, Aquinas can reduce political life to an ultimate divine law even if this law seems to be natural, i.e., non-arbitrary. Our hearts are familiar not only to a "common" (Кotvós) appreciation of what is good and bad but to an essential knowledge which God inscribed in our souls. It suffices to say that Aristotle never claimed that men had a universal, unchangeable, and eternal basis of what is good and bad (see his remarks on "natural right" in $N E$ and Magna moralia). We can deduce that, for Aquinas, natural right is not in conflict with our political life, it rather sustains it. The laws of heaven are not intrinsically opposed to the laws of earth. Conversely, contemplation in the Aristotelean view is in some sense (politically) opposed to human laws since these can be questioned in the tribunal of philosophy, whereas for Thomas, divine law is in its ultimate and most absolute character unquestionable. ${ }^{26}$ This can also be understood by the difference between a contemplation guaranteed by God and the contemplation that is not guaranteed by a loving God, or by the fact that moral virtues, for Aquinas, are in its ultimate stratum connected with God. ${ }^{27}$

The second point we shall emphasize is the distinctive character of this approach to phrónesis when compared to what Franco Volpi called "Neo-Aristotelianism." ${ }^{28}$ He follows Riedel's Rehabilitierung der praktischen Philosophie ${ }^{29}$ and the division of this "rehabilitation" in two moments, the first related to those German thinkers who emigrated to the U.S., namely Leo Strauss, Hannah Aren$\mathrm{dt}$, and Eric Voegelin, and the second related to a much more German systematic

\footnotetext{
${ }^{25}$ Hannah Arendt seems to miss this crucial point since she identifies the Christian view with a radical disdain to vita activa and all worldly occupations. Certainly that's true, yet if contemplation is not possible in this life, then it does not even entail a radical conflict with politics. What she considers much less radical, i.e., the classical Aristotelean view, is actually far more problematic. See, Arendt, The Human Condition (U.S.A.: The University of Chicago Press, 1998), 13, and the reference to Aquinas in $\mathrm{n} 9$.

26 See, Leo Strauss, Natural Right and History, 44-5, 157-164. This can also be understood with what Aristotle and Thomas had in mind when they spoke of the man who cuts himself off from society. Thomas' "example of the superior person whose perfection exceeds the bounds of civil-society is not that of the philosopher, which is presumably what Aristotle had in mind, but that of St. Anthony, a third-century hermit notorious among other things for his opposition to philosophy." Fortin, op. cit., 259.

27 See Leo Strauss, "Jerusalem and Athens," in Studies in Platonic Political Philosophy (U.S.A.: The University of Chicago Press, 1983), $\$ 28$, p. 165 : "For Aristotle it is almost a blasphemy to ascribe justice to his god; he is above justice as well as injustice.” Cf. with $\$ 40$.

${ }^{28}$ Franco Volpi, "The Rehabilitation of Practical Philosophy," in Action and Contemplation, ed. Robert Bartlett and Susan Collins (U.S.A.: State University of New York Press, 1999).

${ }^{29}$ See especially, Joachim Ritter, "Zur Grundlegung der praktischen Philosophie bei Aristoteles," in Rehabilitierung der praktischen Philosophie, vol. 2, ed. Manfred Riedel (Germany: Rombach, 1974).
} 
tradition, such as the Frankfurt school-even if this school tried to be the less systematic possible. Of course, we do not expect Volpi to know every thinker he mentions, but his wrong reference to Leo Strauss as a thinker who had the same intentions as Arendt can be very clarifying. The main claim he attributes to these thinkers of the "rehabilitation" is to restore Aristotelean phrónesis as a means to attack modern Positivism and Rationalism-e.g., Positivist sociology and systematic-metaphysical constructions of ethics and politics. As we can imagine, this recuperation of phrónesis stands or falls by the alleged clear distinction between moral and intellectual virtues, or by the autonomy of prudence in what refers to the particularity of human things. The ultimate claim is, therefore, to establish a much closer relation between philosophy and politics, a commonsensical relation. Volpi is critical at the end with this intention: "Among the neo-Aristotelians, by contrast [to Aristotle himself], the recovery of phronessis runs the risk of missing its goal since phronetic knowledge is here understood within a postmetaphysical horizon, within a horizon which is fairly flat and weaker than Aristotle's; in other words, [it is understood] within a minimal horizon, or even in the absence of any context, of any signpost from which phronetic knowledge could derive any guidance." ${ }^{30}$ When the alleged restoration is understood in these terms, we cannot deny Volpi is right.

However, when it comes to Strauss, it is not evident that this was his intention. Mere words like "The Rebirth of Classical Political Philosophy" are perhaps what at first glance produce this idea. We find e.g. in The City and Man a strong introduction that might also be interpreted as a rehabilitation of classical philosophy in order to attack Positivism and Modernity in general. What seems to be paradoxical—something which Volpi notes—is the attempt to restore just one part of classical philosophy, nay, the particular misinterpretation of one part of classical philosophy, that is, phrónesis without theoria, i.e., to extract the alleged Aristotelean political science in order to resolve our contemporary problems at the same time we disregard the most fundamental concerns of Ancient philosophers. In this sense, as Strauss notes, the contemporary attackers of Modernity are inscribed in the same modern prejudices. ${ }^{31}$

\footnotetext{
30 Volpi, op. cit., 18.

31 "According to the modern project, philosophy or science was no longer to be understood as essentially contemplative and proud but as active and charitable; it was to be in the service of the relief of man's estate" Strauss, CM, 3. We shall ask if, according to the contemporary restoration, philosophy is understood as essentially contemplative. It seems rather that these thinkers are eager to obtain an active and charitable version of Ancient philosophy. There is also, of course, a democratic and even biblical nuance in this eagerness for action and relief; see, Leo Strauss, "Liberal Education and Responsibility," in Liberalism Ancient and Modern (U.S.A.: The University of Chicago Press, 1968), 19-20; Natural Right..., 177, n11.
} 
"We cannot reasonably expect that a fresh understanding of classical political philosophy will supply us with recipes for today's use." ${ }^{2}$ Yet, even if we believe that only through "an adequate understanding" of classical political philosophy we can make intelligible our contemporary crisis, as Strauss himself believed, we still have the obligation of correctly understanding, as far as we can, what this philosophy meant; we cannot just take the parts we like. ${ }^{33}$

In the precise case regarding the Aristotelean division between moral and intellectual virtues, and the distance between Aquinas and the original teaching, we must try to understand first the mediating character of phrónesis which is guided by philosophy as theoria or contemplation. The demands of the philosophical life, which was contemplative at the same time as prudent, might not be as delightful as modern scholars would like.

32 Strauss, CM, 11

$33 \mathrm{Or}$, as we usually hear, we cannot make a "creative transformation," since "it is hard to see how one can speak of a creative transformation of the original teaching if it is not possible to grasp the original teaching as such." ibid., 10. 


\section{Bibliography}

Aquinas, Thomas. Commentary on Aristotle's Politics. Translated by Richard Regan. Indianapolis: Hackett Publishing Company, 2007.

Aquinas, Thomas. Commentary on Nicomachean Ethics. Translated by C. Litzinger and O.P. Chicago: Henry Regnery Company, 1964.

Aquinas, Thomas. On Kingship. Translated by Gerald Pherald. U.S.A.: Hyperion Press, 1979.

Aquinas, Thomas. Summa Contra Gentiles. Translated by Vernon Bourke. New York: Image Books, 1956.

Aquinas, Thomas. Summa Theologica. Translated by Fathers of the English Dominican Province. New York: Benziger Bros, 1947.

Arendt, Hannah. The Human Condition. U.S.A.: The University of Chicago Press, 1998.

Aristotle. Ethica Nicomachea. Edited by J. Bywater. Oxford: Clarendon Press, 1894.

Aristotle. Metaphysics. Translated by Joe Sachs. U.S.A.: Green Lion Press, 1999.

Aristotle. "Metaphysics A.” In Aristotle’s Metaphysics Alfa, edited by Carlos Steel. U.K.: Oxford University Press, 2012.

Aristotle. Nicomachean Ethics. Translated by Robert Bartlett and Susan Collins. U.S.A.: The University of Chicago Press, 2011.

Aristotle. Posterior Analytics-Topica. Translated by E.S. Forster. G.B.: William Heinemann LTD, 1960.

Aristotle. Politics. Translated by H. Rackham. G.B.: William Heinemann LTD, 1959.

Bartlett, Robert, and Susan Collins (eds.). Action and Contemplation. U.S.A: State University of New York Press, 1999.

Cicero. Tusculan Disputations. Translated by Andrew Peabody. Boston: Little, Brown, and Company, 1886.

Fortin, Ernest. "St. Thomas Aquinas." In Strauss, Leo, and Joseph Cropsey (eds.). History of Political Philosophy. U.S.A.: The University of Chicago Press, 1987. 
Foucault, Michel. The Hermeneutics of the Subject. Translated by Graham Burchell. U.S.A.: Palgrave Macmillan, 2005.

Heidegger, Martin. Phänomenologische Interpretationen Zu Aristoteles (Anzeige Der Hermeneutischen Situation). In Gesamtausgabe, Bd. 62. Edited by G. von Neumann. Frankfurt: Vittorio Klostermann, 2005.

Jaeger, Werner. Aristotle. Translated by Richard Robinson. Oxford: Clarendon Press, 1968.

Jaffa, Harry. Thomism and Aristotelianism. U.S.A.: The University of Chicago Press, 1952.

Lord, Carnes. "Aristotle." In Strauss, Leo, and Joseph Cropsey (eds.). History of Political Philosophy. U.S.A.: The University of Chicago Press, 1987.

Meier, Heinrich. Leo Strauss and the Theologico-Political Problem. Translated by Marcus Brainard. U.S.A.: Cambridge University Press, 2006.

Meier, Heinrich. "Why Political Philosophy?" The Review of Metaphysics 56, no. 2 (2002): 385-407.

Minkov, Svetozar. Leo Strauss on Science. U.S.A.: State University of New York Press, 2016.

Oehler, Klaus. "Thomas von Aquin als Interpret der aristotelischen Ethik.” Philosophische Rundschau, 5 (1957): 132-152.

Plato. Statesman. Edited and translated by C. Rowe. England: Aris \& Phillips Ltd, 1995.

Reeve, C. Action, Contemplation, and Happiness. An Essay on Aristotle. U.S.A.: Harvard University Press, 2012.

Reeve, C. "Aristotle's Philosophical Method." In The Oxford Handbook of Aristotle, edited by Christopher Shields. Oxford: Oxford University Press, 2012.

Ritter, Joachim. "Zur Grundlegung Der Praktischen Philosophie Bei Aristoteles." In Rehabilitierung Der Praktischen Philosophie, edited by Manfred Riedel. Germany: Rombach, 1974.

Shields, Christopher (ed.). The Oxford Handbook of Aristotle, edited by Christopher Shields. Oxford: Oxford University Press, 2012

Strauss, Leo. Liberalism Ancient and Modern. U.S.A.: The University of Chicago Press, 1968. 
Strauss, Leo. Natural Right and History. U.S.A.: The University of Chicago Press, 1965.

Strauss, Leo. On Tyranny. Edited by Victor Gourevitch and Michael Roth. U.S.A.: The University of Chicago Press, 2000.

Strauss, Leo. Studies in Platonic Political Philosophy. U.S.A.: The University of Chicago Press, 1983.

Strauss, Leo. The City and Man. U.S.A.: The University of Chicago Press, 1964.

Strauss, Leo, and Joseph Cropsey (eds.). History of Political Philosophy. U.S.A.: The University of Chicago Press, 1987.

Volpi, Franco. "The Rehabilitation of Practical Philosophy." In Action and Contemplation, edited by Robert Bartlett and Susan Collins. U.S.A.: State University of New York Press, 1999.

Xenophon. Memorabilia-Oeconomicus-Symposium-Apology. Translated by E. Marchant. London: St Edmundsbury Press Ltd, 1997.

DOI: https://doi.org/10.15366/bp2021.27.001

Bajo Palabra. II Época. No 27. Pgs: 21-44 
